\title{
Exceptionally preserved extracellular bone matrix proteins from the late Neogene proboscidean Anancus (Mammalia: Proboscidea)
}

\author{
Tyede H. Schmidt-Schultz ${ }^{1}$ - Mike Reich ${ }^{2,3,4}$ - Michael Schultz ${ }^{1,5}$
}

Received: 10 January 2021 / Accepted: 30 April 2021 / Published online: 14 June 2021

(c) The Author(s) 2021

\begin{abstract}
In an exceptional preservation state, bones conserve the entire pattern of extracellular bone matrix proteins over thousands or sometimes even millions of years. Here we present typical extracellular bone matrix proteins, which were extracted from a 3.0-million-year-old gomphothere proboscidean, and identified with special antibodies. For the first time, osteonectin, osteopontin and BMP-2 were confidently identified from the extinct Anancus arvernensis, based on late Pliocene material from Willershausen, Lower Saxony, Germany. Our study has value in demonstrating that the longevity of original extracellular bone matrix proteins is much greater than formerly expected, and that such materials may be stabilised for distinct geological periods of time, especially in Fossil Lagerstätten.
\end{abstract}

Keywords Proteomics $\cdot$ Extracellular bone matrix proteins $\cdot$ Proboscidea $\cdot$ Pliocene $\cdot$ Konservat Lagerstätte · Willershausen · Germany

\section{Introduction}

Handling Editor: Joachim Reitner.

Mike Reich

reich@snsb.de; mike.reich@lmu.de

$\triangle$ Michael Schultz mschult1@gwdg.de

1 Department of Anatomy and Embryology, Center of Anatomy, Georg-August University of Göttingen, Kreuzbergring 36, 37075 Goettingen, Germany

2 SNSB - Bavarian State Collection of Palaeontology and Geology, Richard-Wagner-Str. 10, 80333 Munich, Germany

3 Department of Earth and Environmental Sciences, Palaeontology and Geobiology, Ludwig-Maximilians-Universität München, Richard-Wagner-Str. 10, 80333 Munich, Germany

4 GeoBio-Center LMU, Richard-Wagner-Str. 10, 80333 Munich, Germany

5 Department of Biology, Institute of Biology and Chemistry, University of Hildesheim, Universitätsplatz 1,

31141 Hildesheim, Germany
Biological molecules have varying stabilities and preservation potential over extended periods which depending on where these molecules performed their metabolic function during lifetime (e.g., overviews in Demarchi et al. 2016; Ehrlich et al. 2013; Thomas and Taylor 2019; Wysokowski et al. 2014). Molecules, which were synthesized by osteoblasts and secreted to the extracellular matrix (ECM), build the organic part of the bone matrix, an array of proteins collectively termed osteoid. ECM of bone contains only $10 \%$ water, whereas cells have a water content of more than $70 \%$. ECM-proteins are embedded and bounded to the calcified structures (e.g., calcium phosphates, comparable with hydroxyapatite) and to collagen. Immediately after the cell death, the molecules inside a cell start rapid degeneration (Morgan et al. 2008). Therefore, the chance to survive over a long time span after death is much better for ECM-proteins than for proteins inside of cells.

The present study deals with the analysis of typical extracellular bone matrix proteins taken from cortical bone of the femur of a late Pliocene gomphothere proboscidean (Anancus arvernensis; Elephantidae; Klähn 1932; Göhlich 2012; Karl et al. 2013). The exceptional preservation of these proteins (cf. also Buckley and Wadsworth 2014; Wadsworth and 
Buckley 2014) and other biomolecules and chemical compounds (e.g., Keely et al. 1994; Manning et al. 2019; Wolkenstein and Arp 2021) was caused by special taphonomic features, well known from the limnic Konservat Lagerstätte Willershausen (e.g., Briggs et al. 1998; Briggs 1999).

\section{Materials and methods}

A small (ca. $6 \times 8 \mathrm{~mm}$ ) and a large (ca. $18 \times 8 \mathrm{~mm}$ ) sample were taken for microscopic and biochemical (proteomic) analyses from the cortex of the neck of the left femur (GZG.W.35028) of the approximately 3.0-million-year-old extinct proboscidean (Anancus arvernensis) from Willershausen, western foreland of the Harz Mts., which dates from the late Neogene time (Pliocene: Piacenzian; e.g., Wegele 1914; Brauckmann and Gröning 2002).

In the former clay pit of Willershausen, dark laminated clays containing a single carbonate horizon were exposed. These sediments were deposited in a small meromictic lake with anoxic, hyaline bottom water (Meischner and Paul 1982; Meischner 1995, 2000). The great majority of Willershausen fossils have been excavated from the carbonatic sediments (e.g., Krüger 1979; Meischner and Paul 1982; Meischner 1995, 2000; Dlussky et al. 2011; Kolibáč et al. 2016). This site is well known for exceptionally preserved fossils, including cuticles (e.g., Straus 1969; Briggs et al. 1998; Knobloch 1998) and soft parts (e.g., Westphal 1967; Straus 1969; Rietschel and Storch 1974; Spinar 1980; Gehler and Reich 2012; Wolkenstein and Arp 2021). However, the material used in our study was found in the clay during a fossil-digging campaign in the early 1930s, and is part of a partial skeleton of Anancus arvernensis (Fig. 1; see Klähn 1932; Reich and Gehler 2011; deposited at the Geoscience Centre of the Georg-August University of Göttingen, GZG).

From each sample, two thin-ground sections were prepared according to the procedure described by Schultz and Brandt (Schultz 1988, 2001; Schultz and Drommer 1983). These thin-ground sections were established as cross sections at right angles to the longitudinal axis of the femur neck to investigate the morphological integrity, as well as the diagenetic overprint and the degree of fossilization, to rule out possible contamination (Schultz 1997). The thinground sections with a thickness of 20-40 $\mu \mathrm{m}$ were studied through the microscope (Leica DM-RXP/DFC 500) in plain and polarized transmission light using a hilfsobject red first order (quartz) as compensator ( $\lambda$-plate).

The ECM-proteins were extracted as previously described (Schmidt-Schultz and Schultz 2004, 2005; Schultz et al. 2007). The proteins were resolved by sodium dodecylsulfate polyacrylamide gel electrophoresis (Laemmli 1970) and stained with silver (Swain and Ross 1995).

The 2-D-electrophoresis separates proteins by their isoelectrical point (IPG-strips $7 \mathrm{~cm} \mathrm{pH} \mathrm{3-10,} \mathrm{BioRad} \mathrm{USA).}$ IPGs are transferred to the SDS-Page without stacking gel and separated by their molecular weight and also stained with silver. This procedure represents an overview about the quantity of ECM-proteins in the proboscidean bone.

In Western Blot, proteins were identified using special antibodies. In this case, BMP-2 (1:400, Santa Cruz, Inc., USA), osteopontin (1:1000, Calbiochem, CA, USA) and osteonectin (1:1000, Chemicon, CA, USA) were investigated. Horseradish peroxidase (HRP)-linked anti-goat (1:5000, DAKO, Denmark) and HRP-anti rabbit (1:100.000,
Fig. 1 Partial semi-articulated skeleton of Anancus arvernensis, excavated from the Pliocene (Piacenzian) clay of Willershausen by Hermann Schmidt in 1930 (sitting here in the picture; GZG archive), former curator of the Göttingen geological collections. The investigated (incomplete) left femur (GZG.W.35028) is indicated by a red arrow

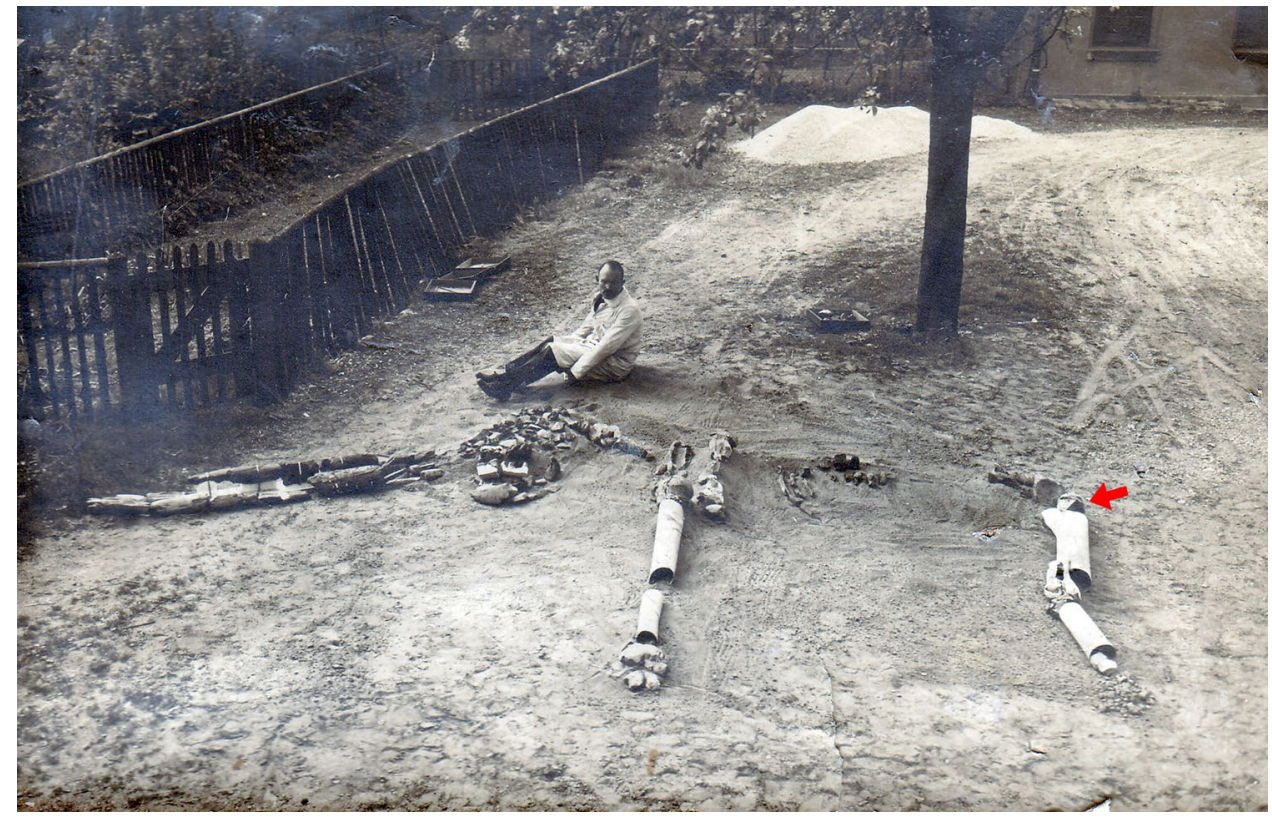


DIANOVA, Hamburg, Germany) were used as secondary antibodies. Bands were visualized using enhanced chemiluminescence (ECL)-Plus detection system (Health Care, Freiburg, Germany).

\section{Results}

No obvious signs of a strong fossilization process and only minor vestiges of diagenetic alterations could be observed in the bone matrix of the investigated samples (Fig. 2). As the light microscopic investigation showed, the external zone of the bone, containing the external circumferential lamellae, the external tangential lamellae and some blood vessel
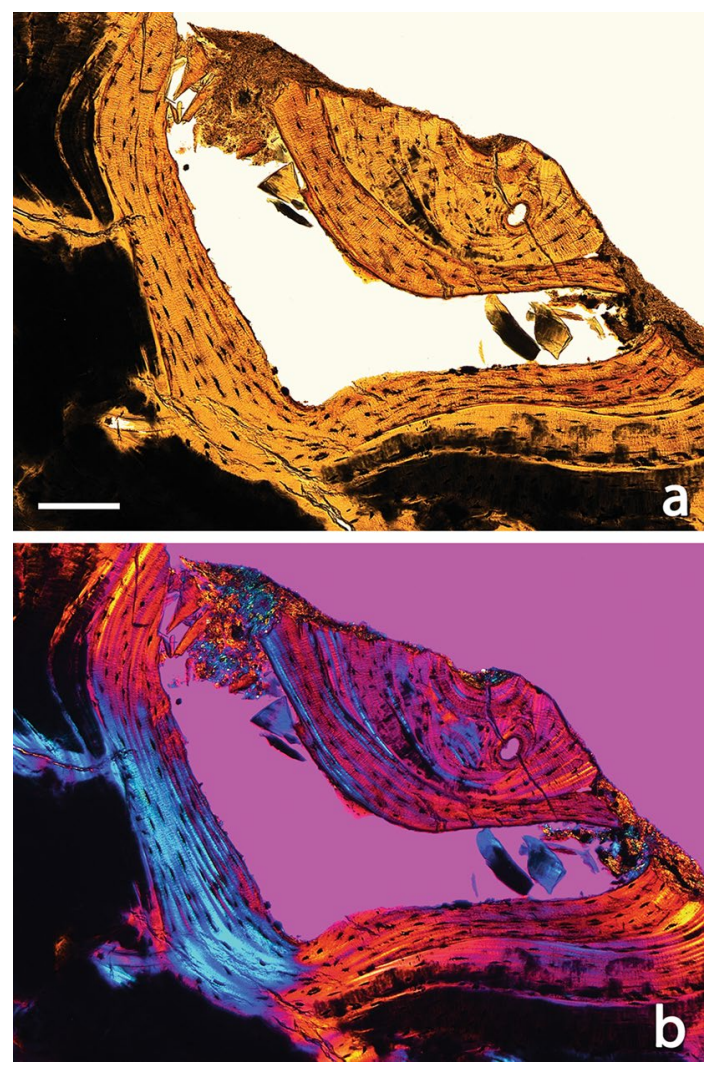

Fig. 2 Thin-ground section prepared with a thickness of $20 \mu \mathrm{m}$ from the cortex of the neck of the left femur (small sample) of Willershausen Anancus arvernensis viewed through the microscope in plain (a) and polarized transmission light using a red first order (quartz) hilfsobject as compensator (b). The external bone surface has been slightly eroded postmortem during embedding and diagenesis. As a result, larger bone particles and smallest bone fragments burst and partially filled secondary external vascular channels. Scale bar $160 \mu \mathrm{m}$

canals (e.g., Haversian canals) of the cortex, is exceptionally well preserved (Figs. 3, 4). The blasting of external thin bone layer (Fig. 4) was apparently caused by the tension formed during the million-year-long storage in the ground and built up as a result of lithification and load of sediment. At the first view, the larger internal zone including the endosteal zone is not as well preserved as the external (Figs. 3, 5). These areas show in the plain, as well as in the polarized transmission light, a cloudy dark appearance (Figs. 3, 5a, b, 6, 7) which might be due to the original embedding of the Anancus skeleton in dark clays, deposited under anoxic bottom conditions in the center of the former Willershausen pond. If the transmission light is significantly intensified, i.e., overexposed, well organized, regular collagen fibers become visible in the polarized light, which are ordered and expressed in the same way as the fibers in the external zone (Figs. 5c, 7c, d). The presence of these welldeveloped fibers shows that the cloudy, dark appearance of
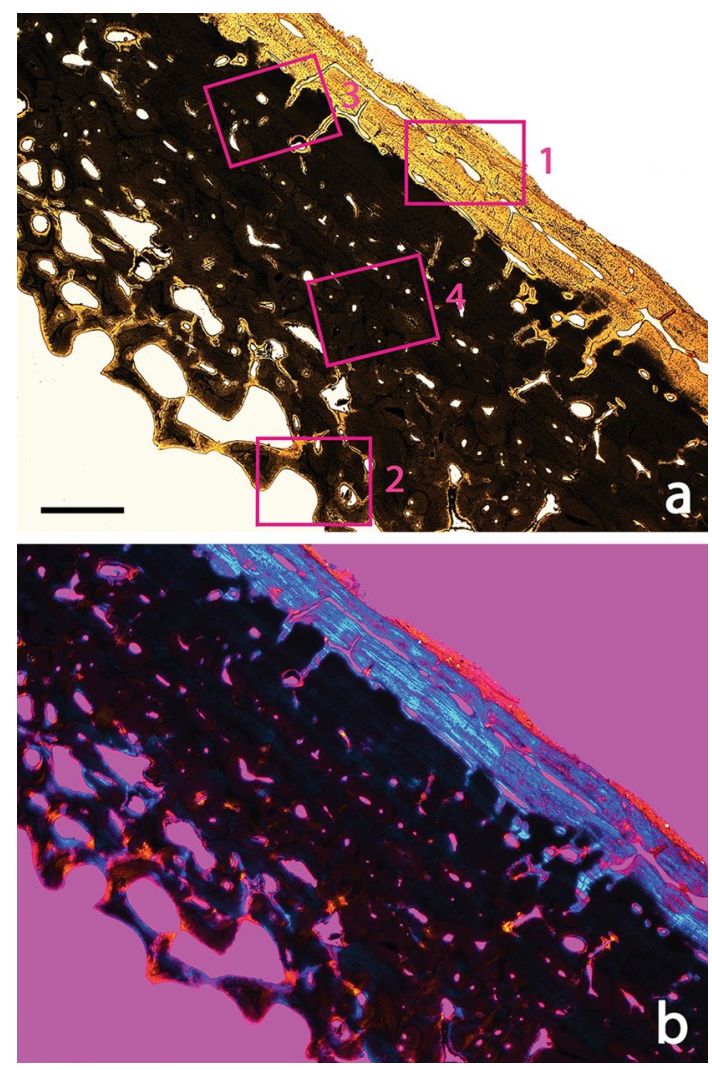

Fig. 3 Thin-ground section prepared with a thickness of $20 \mu \mathrm{m}$ from the cortex of the neck of the left femur (large sample) of Willershausen Anancus arvernensis viewed through the microscope in plain (a) and polarized transmission light using a red first order (quartz) hilfsobject as compensator (b). The bone tissue in the external area is particularly well preserved. The magenta-colored frames mark the position of the cutout magnifications: $1=$ Fig. $4 ; 2=$ Fig. $5 ; 3=$ Fig. 6 ; $4=$ Fig. 7 . Scale bar $1 \mathrm{~mm}$

the bony tissue (Figs. 3, 5a, b, 6, 7a) was not caused by the diagenetic action of micro-organisms and that the original bone substance including its matrix is also well preserved 

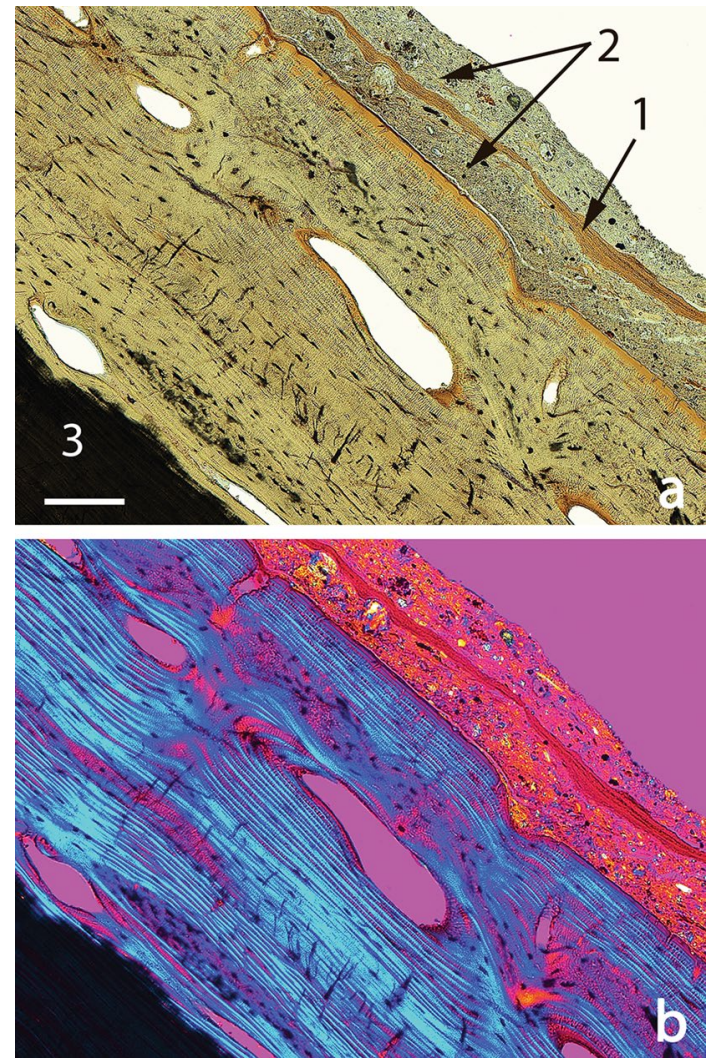

Fig. 4 Thin-ground section prepared with a thickness of $20 \mu \mathrm{m}$ from the cortex of the neck of the left femur (large sample) of Willershausen Anancus arvernensis viewed through the microscope in plain (a) and polarized transmission light using a red first order (quartz) hilfsobject as compensator (b). The external area is particularly well preserved. $1=$ Splintered external layer of the cortex; $2=$ Sediment fillings above and below the chipped lamella, formed after embedding, during lithification; $3=$ Medium, at first glance poorly preserved area of the cortex. Scale bar $160 \mu \mathrm{m}$

in these dark areas. Thus, the bony tissue was secondarily pigmented by the dark embedding sediment. This result is extremely important and an absolute prerequisite for further biochemical, i.e., proteomic analysis.

The extracted proteins, which represent typical ECMs, were resolved by SDS-Page according to their molecular weight (Fig. 8a). A clear pattern of about 25 different colored bands, stained with silver, in the range of about $10-250 \mathrm{kDa}$ could be detected. In the 2-D electrophoresis more than 300 different protein spots were stained with silver (Fig. 8b). Even if we consider that several of the extracted matrix proteins represent isoenzymes or proteins with different glycosylation groups, we are sure that most ECM-proteins can also be solubilized from a 3.0-million-year-old fossil bone.

Also in western blot we checked for osteopontin, osteonectin and BMP-2. It was possible to identify all three ECMs with their correct molecular weight: osteopontin $45 \mathrm{kDa}$, osteonectin $40 \mathrm{kDa}$ and BMP-2 $28 \mathrm{kDa}$ (Fig. 8c).
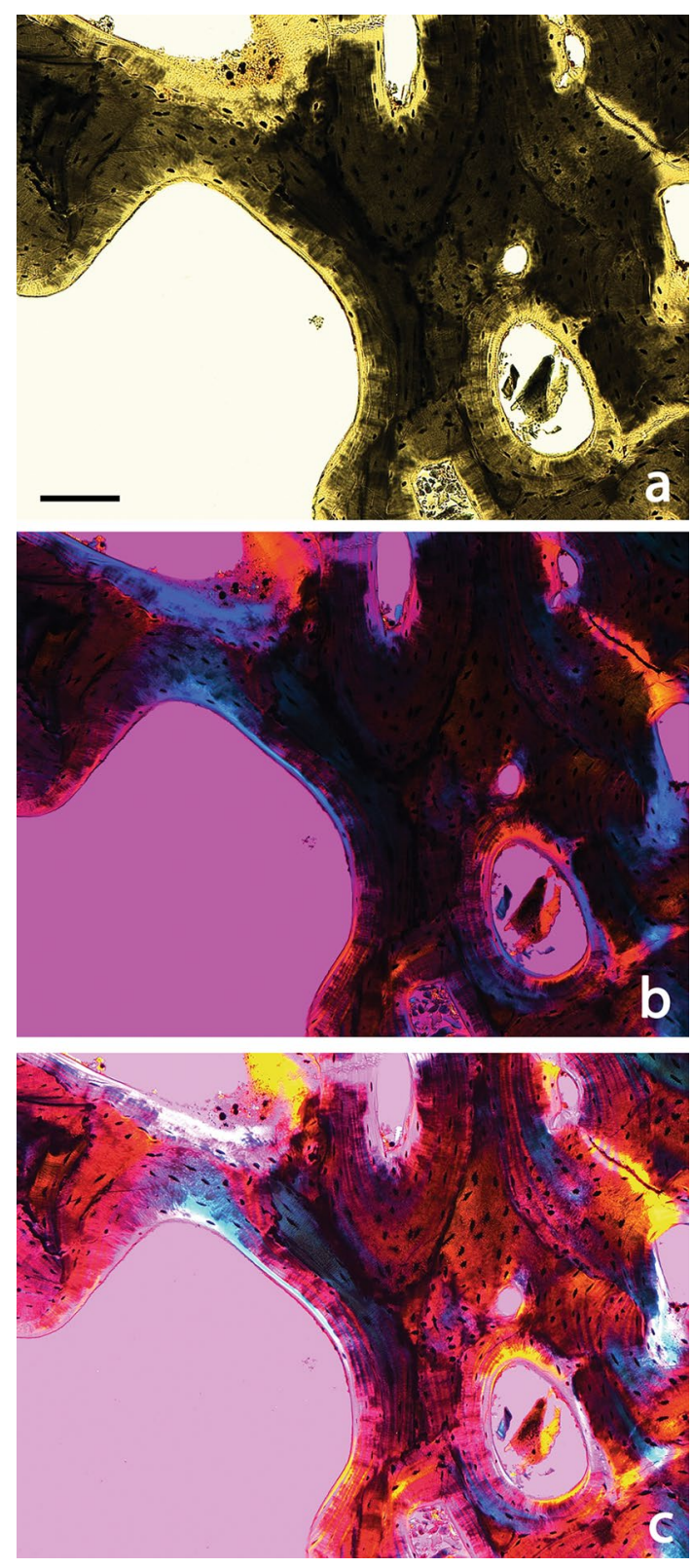

Fig. 5 Thin-ground section prepared with a thickness of $20 \mu \mathrm{m}$ from the cortex of the neck of the left femur (large sample) of Willershausen Anancus arvernensis viewed through the microscope in plain (a) and polarized transmission light using a red first order (quartz) hilfsobject as compensator (b) and (c). The endosteal zone of the cortex does not seem to be as good as the outer zone preserved (a and $\mathbf{b}$ ); in the overexposure, however, the collagen fibers present themselves very well and prove a comparatively good condition (c). Scale bar $160 \mu \mathrm{m}$

The antibody reactions were controlled by their special blocking peptides. 


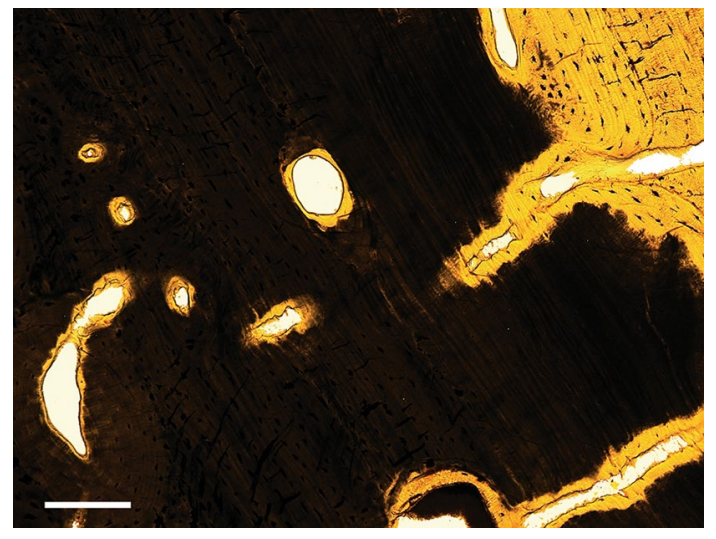

Fig. 6 Thin-ground section prepared with a thickness of $20 \mu \mathrm{m}$ from the cortex of the neck of the left femur (large sample) of Willershausen Anancus arvernensis viewed through the microscope in plain transmission light. The bone structure located in the middle area of the cortex shows no details in the plain transmission light. Scale bar $160 \mu \mathrm{m}$
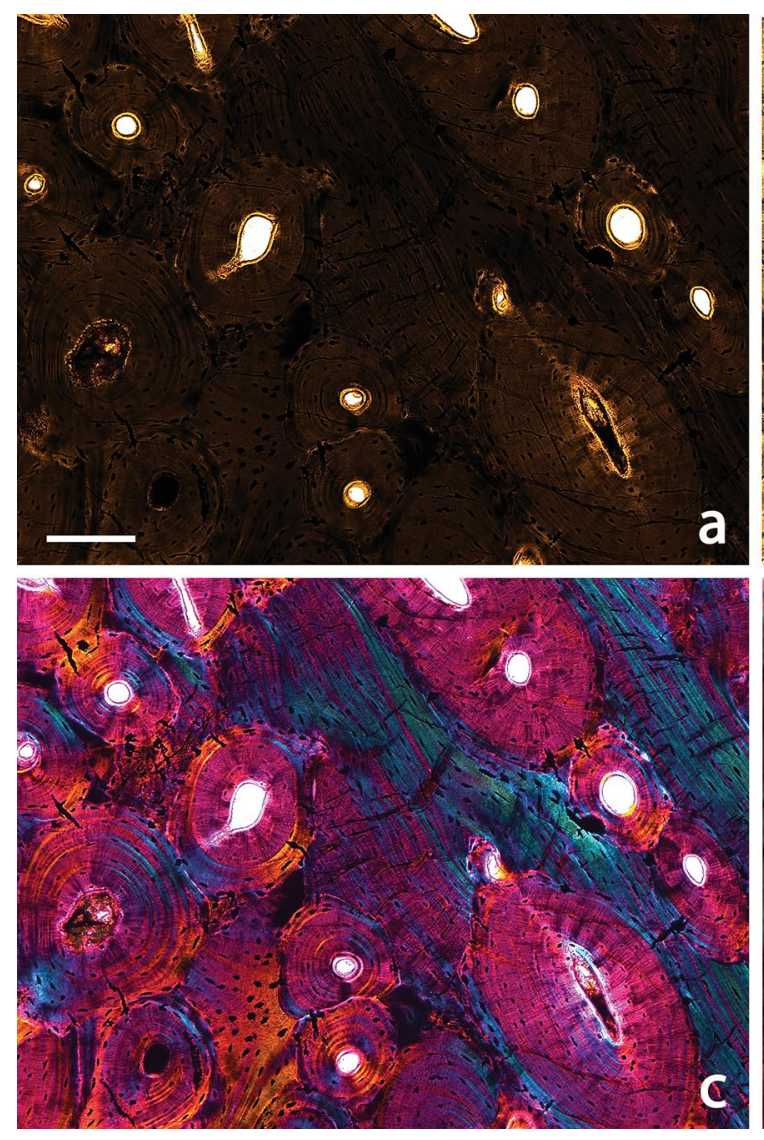

Fig. 7 Thin-ground section prepared with a thickness of $20 \mu \mathrm{m}$ from the cortex of the neck of the left femur (large sample) of Willershausen Anancus arvernensis viewed through the microscope in plain (a) and (b) and polarized transmission light using a red first order (quartz) hilfsobject as compensator (c) and (d); b and $\mathbf{c}$ overexposed.
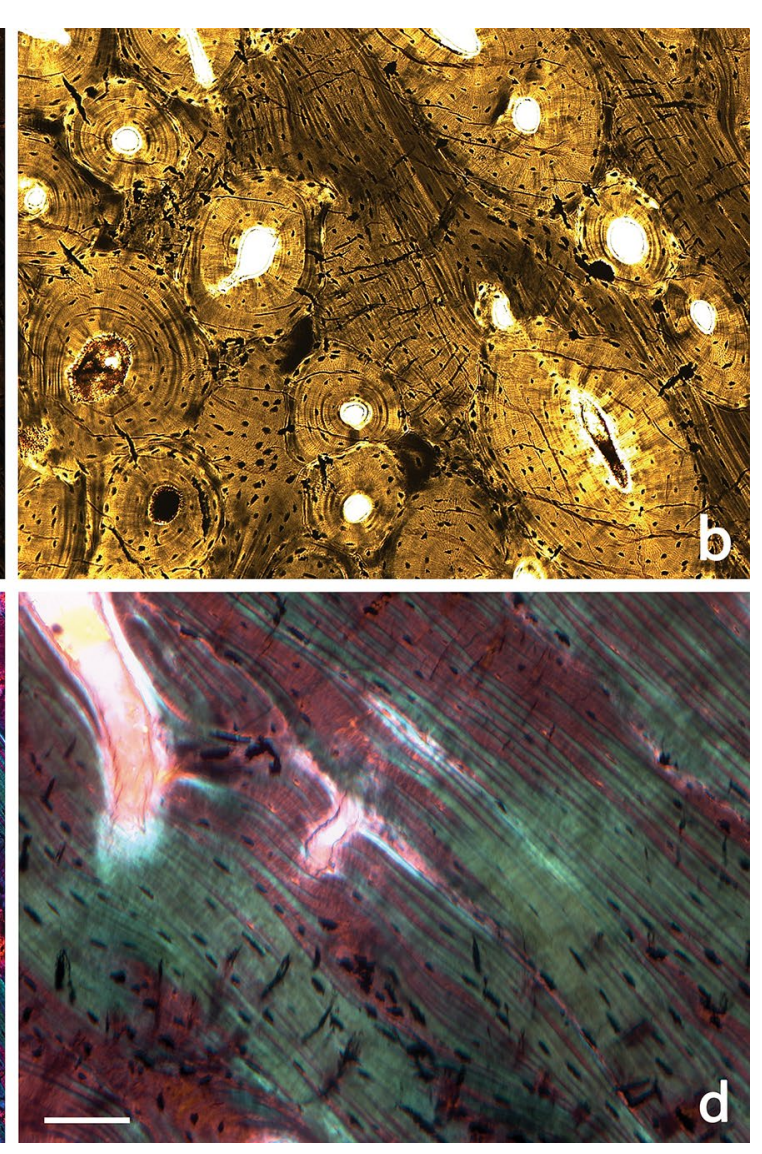

\section{Discussion}

The result of the microscopic examination in plain transmission light gives the impression at first glance that the embedding of bone tissue in a former meromictic pond is not conducive to the preservational status of the collagen (cf. Schultz 1997) and other ECMs (Figs. 3, 5a, b, 6, 7a). However, the collagen fibers and apparently the other proteins of the extracellular bone matrix are not affected in their state of preservation, as shown by our proteomic analysis. This finding is supported by the study of thin-ground sections in polarized transmission light, in which the collagen fibers present themselves as well preserved in case of overexposure (Figs. 5c, 7c, d). It can therefore be assumed that the embedding of bones in a limnic Konservat Lagerstätte also preserves the extracellular bone matrix and does not damage its preservation. The phenomenon of the cloudy dark appearance in the microscopic examination of the thin-ground sections, which is apparently due to the original embedding of the Anancus skeleton in dark clays, can

In the overexposure, the collagen fibers present themselves very well and prove a comparatively good condition. In the overexposure it can be seen that the collagen fibers are well to very well preserved. Scale bars $160 \mu \mathrm{m}(\mathbf{a}-\mathbf{c}), 64 \mu \mathrm{m}(\mathbf{d})$ 


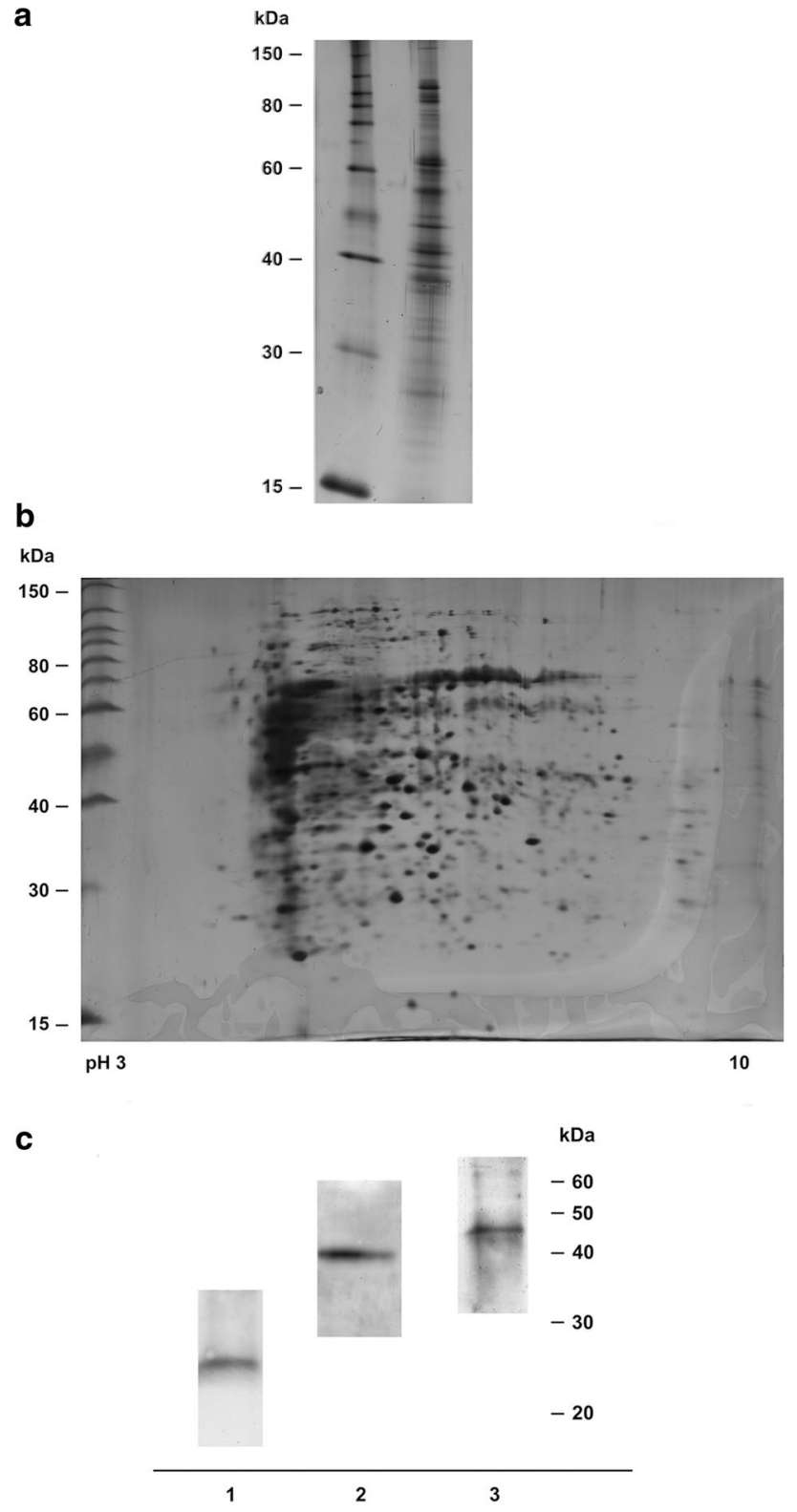

Fig. 8 Results of the biochemical analyses: a 1-D-electrophoresis $(11 \% \mathrm{~T}, 2.5 \% \mathrm{C}) \mathrm{ECM}$-proteins stained with silver. Left lane: molecular weight marker. Right lane: ECM-proteins of the Willershausen Anancus arvernensis femur. b 2-D-electrophoresis of ECM-proteins of the Anancus femur stained with silver. First dimension IPG-strip $\mathrm{pH} 3-10$, second dimension SDS-PAGE $(11 \% \mathrm{~T}, 2.5 \% \mathrm{C})$, on the left, mass marker. c Identification of Anancus ECMs using specific antibodies. Band 1: bone morphogenetic protein-2 (BMP-2). Band 2: osteonectin. Band 3: osteopontin. On the right: molecular weight marker

possibly be associated with the Maillard reaction products (Wiemann et al. 2018).

BMP-2 has pleiotrophic functions that range from skeletal and extra skeletal organ genesis to generation and regeneration of bone and, additionally, recapitulates the process of embryonic and enchondral ossification and induces bone formation in postfetal life. Thus, BMPs are members of a class of ancient highly conserved signaling molecules that play major roles in embryonic axis determination, organ development, and tissue repair through the animal kingdom (Kaplan and Shore 1998). Osteopontin has a Gly-ArgGly-Asp-Ser (GRGDS) aminoacid sequence that promotes osteoclast attachment via cellular integrin $\alpha_{\mathrm{v}} \beta_{3}$ (Reinholt et al. 1990; Heinegard 1995). The expression of osteonectin (SPARC) is increased in tissues undergoing repair or remodeling due to wound healing, however, particularly in pathological processes, such as formation of cancer metastases, arthritis, diabetes or kidney (Reed and Sage 1996). Up to now, osteonectin, osteopontin and BMP-2 were not identified in a 3-million-year-old proboscidean bone.

Since the late 1980s, several articles were published dealing with the topic ECM-proteins in mastodon bones (Tuross 1989; Schaedler et al. 1992; Asara et al. 2007). In a South American, about 11,000-13,000-year-old radiocarbon dated mastodon skeleton, Schaedler and co-workers microscopically looked for collagen fibers. They compared in gel electrophoresis $\mathrm{CNBr}$ peptides of the demineralized bone matrix, obtained from the mastodon (Mammutidae), with the results of mammoth (Elephantidae), modern elephant and rat tail tendon (Schaedler et al. 1992). In the bone of Taima-Taima mastodon, Tuross (1989) looked for the pattern of amino acids, however, as a drawback of this technique, she could not obtain information about the completely preserved matrix proteins (Tuross 1989). In gel electrophoresis, Tuross (1989) detected three different protein bands, for one band she supposed the presence of albumin because of the similar molecular weight. Other related investigations on Pleistocene mammals were published recently (e.g., Cappellini et al. 2012; Hill et al. 2015; Kostyukevich et al. 2018).

Particularly Schweitzer and her group (Schweitzer et al. 2013), who was very active and successful during the last 15 years, sequenced protein fragments from bone collagen of a 100,000 to 600,000 -year-old mastodon and a 68-millionyear-old dinosaur (Asara et al. 2007). However, also other groups identified non-collagenous ECM proteins such as osteonectin and osteopontin in 120 ky Pleistocene mammals using mass spectrometry (Cappellini et al. 2012; Hill et al. 2015; Kostyukevich et al. 2018), while Kostyukevich and colleagues also detected with coupled liquid chromatography lipids (Kostyukevich et al. 2018). Also impressive is the work of Cappellini and his group dealing with tandem mass spectrometry which enables the sequencing of collagen type 1 from a 1.5-million-year-old sample of a tooth from Cretaceous fossil remains (Cappellini et al. 2019). The presence of osteocytes and endogenous molecules found by this investigation is exciting (Cleland et al. 2012). Although the perspective is encouraging for future biochemical research on ancient bones, it is unlikely that one will be able to isolate and identify intact cellular proteins, since after death the cell 
proteins, along with the decay of the cells, are also broken down very quickly.

Our ECM-proteins extraction protocol differs from most other protocols. After demineralization and centrifugation, most researchers suppose that all the proteins are solubilized in the supernatant after this procedure. Therefore, they use in the further investigation only the supernatants. Cleland and co-workers as well as Schweitzer and co-workers compared, discussed and summed up the various extraction protocols (Cleland et al. 2012; Schweitzer et al. 2013). We have found that, after the demineralization process, only a few ECM proteins are solubilized in the supernatant, however, most proteins apparently are still bound very tightly to the residuals of minerals and collagens in the pellet (cf. also Demarchi et al. 2016). We do not use the supernatants for further investigations because protein fragments have high affinity to the bone matrix, which of course also applies to the broken down proteins from other organs, protein fragments from previous investigators, and protein fragments of contaminants from outside, these proteins can be detached more easily and are then in the supernatant. Thus, we solubilized the proteins from the partly demineralized and hence dispersed pellet (Schmidt-Schultz and Schultz 2004, 2005; Schultz et al. 2007). This methodical approach enables researchers to identify various typical bone matrix proteins and also proteins which can support the diagnosis of pathological conditions in dry bone (Schultz et al. 2007).

\section{Conclusions}

In our study, we have clearly shown that original extracellular bone matrix proteins, despite slightly diagenetic alteration, can be extracted from bones $\sim 3$ million years old. Given the success in the late Pliocene Anancus arvernensis material from Willershausen, a limnic Konservat Lagerstätte, the potential for further biochemical (proteomic) studies on older bone material from Paleogene or Mesozoic Fossil Lagerstätten, that can be obtained using specific extraction methods, is evident.

Additionally, using microscopic techniques, micro-morphological changes and characteristics in bones that are of interest to check the diagenetic alteration and to reconstruct taphonomic pathways and the former palaeoenvironment, were presented.

Acknowledgements The authors would like to thank Michael Brandt, Department of Anatomy, University Medical School Göttingen, Conny Hundertmark and Lina Leschner, both Department of Geobiology/ Geoscience Museum, Geoscience Centre Göttingen, for technical assistance. Thanks also to Joachim Reitner and Alexander Gehler, Department of Geobiology, Göttingen Geoscience Centre for fruitful discussions. The valuable comments of two anonymous reviewers greatly improved the quality of our paper. The University of Göttingen provided funding.

Funding Open Access funding enabled and organized by Projekt DEAL.

Open Access This article is licensed under a Creative Commons Attribution 4.0 International License, which permits use, sharing, adaptation, distribution and reproduction in any medium or format, as long as you give appropriate credit to the original author(s) and the source, provide a link to the Creative Commons licence, and indicate if changes were made. The images or other third party material in this article are included in the article's Creative Commons licence, unless indicated otherwise in a credit line to the material. If material is not included in the article's Creative Commons licence and your intended use is not permitted by statutory regulation or exceeds the permitted use, you will need to obtain permission directly from the copyright holder. To view a copy of this licence, visit http://creativecommons.org/licenses/by/4.0/.

\section{References}

Asara, J.M., M.H. Schweitzer, L.M. Freimark, M. Phillips, and L.C. Cantley. 2007. Protein sequences from mastodon and Tyrannosaurus rex revealed by mass spectrometry. Science 316: 280-285. https://doi.org/10.1126/science.1137614.

Brauckmann, C., and E. Gröning. 2002. Neue Funde von Singzikaden (Hemiptera: Cicadidae) aus dem Jung-Tertiär von Willershausen am Harz. Mitteilungen des Naturwissenschaftlichen Vereins Goslar 7: 83-92.

Briggs, D.E.G. 1999. Molecular taphonomy of animal and plant cuticles: selective preservation and diagenesis. Philosophical Transactions of the Royal Society (B: Biological Sciences) 354: 7-17. https://doi.org/10.1098/rstb.1999.0356.

Briggs, D.E.G., B.A. Stankiewicz, D. Meischner, A. Bierstedt, and R.P. Evershed. 1998. Taphonomy of Arthropod Cuticles from Pliocene Lake Sediments, Willershausen, Germany. Palaios 13: 386-394. https://doi.org/10.2307/3515326.

Buckley, M., and C. Wadsworth. 2014. Proteome degradation in ancient bone: diagenesis and phylogenetic potential. Palaeogeography, Palaeoclimatology, Palaeoecology 416: 69-79. https://doi.org/10. 1016/j.palaeo.2014.06.026.

Cappellini, E., L.J. Jensen, D. Szklarczyk, A. Ginolhac, and A.R. da Rute. 2012. Proteomic analysis of a Pleistocene mammoth femur reveals more than one hundred ancient bone proteins. Journal of Proteome Research 11(2): 917-926. https://doi.org/10.1021/ pr200721u.

Cappellini, E., F. Welker, L. Pandolfi, J. Ramos-Madrigal, D. Samodova, P.L. Rüther, A.K. Fotakis, D. Lyon, J.V. Moreno-Mayar, M. Bukhsianidze, R.R. Jersie-Cristensen, M. Mackie, A. Ginolhac, R. Ferring, M. Tappen, E. Palkopoulou, M.R. Dickinson, T.W. Stafford Jr., Y. Chan, A. Götherström, S.K.S.S. Nathan, P.D. Heintzman, J.D. Kapp, I. Kirillova, Y. Moodley, J. Agusti, R.-D. Kahlke, G. Kiladze, B. Martínez-Navarro, S. Liu, M. Sandoval Velasco, M.-H.S. Sinding, C.D. Kelstrup, M.E. Allentoft, L. Orlando, K. Penkman, B. Shapiro, L. Rook, L. Dalén, M.T.P. Gilbert, J.V. Olsen, D. Lordkipanidze, and E. Willerslev. 2019. Early Pleistocene enamel proteome from Dmanisi resolve Stephanorhinus phylogeny. Nature 574(7776): 103-107. https://doi.org/10.1038/ s41586-019-1555-y.

Cleland, T.P., K. Voegele, and M.H. Schweitzer. 2012. Empirical evaluation of bone extraction protocols. PLOS ONE 7: e31443. https:// doi.org/10.1371/journal.pone.0031443. 
Demarchi, B., S. Hall, T. Roncal-Herrero, C.L. Freeman, J. Woolley, M.K. Crisp, J. Wilson, A. Fotakis, R. Fischer, B.M. Kessler, R. Rakownikow Jersie-Christensen, J.V. Olsen, J. Haile, J. Thomas, C.W. Marean, J. Parkington, S. Presslee, J. Lee-Thorp, P. Ditchfield, J.F. Hamilton, M.W. Ward, C.M. Wang, M.D. Shaw, T. Harrison, M. Domínguez-Rodrigo, R.D.E. MacPhee, A. Kwekason, M. Ecker, L. Kolska Horwitz, M. Chazan, R. Kröger, J. ThomasOates, J.H. Harding, E. Cappellini, K. Penkman, and M.J. Collins. 2016. Protein sequences bound to mineral surfaces persist into dep time. eLife 2016(5): e17092. https://doi.org/10.7554/eLife.17092.

Dlussky, G.M., H.-V. Karl, C. Brauckmann, E. Gröning, and M. Reich. 2011. Two ants (Insecta: Hymenoptera: Formicidae: Formicinae) from the Late Pliocene of Willershausen, Germany, with a nomenclatural note on the genus Camponotites. Paläontologische Zeitschrift 85: 449-455. https://doi.org/10.1007/ s12542-011-0104-2.

Ehrlich, H., J.K. Rigby, J.P. Botting, M.V. Tsurkan, C. Werner, P. Schwille, Z. Petrášek, A. Pisera, P. Simon, V.N. Sivkov, D.V. Vyalikh, S.L. Molodtsov, D. Kurek, M. Kammer, S. Hunoldt, R. Born, D. Stawski, A. Steinhof, V.V. Bazhenov, and T. Geisler. 2013. Discovery of 505-million-year old chitin in the basal demosponge Vauxia gracilenta. Scientific Reports 3: 3497. https://doi. org/10.1038/srep03497.

Gehler, A., and M. Reich. 2012. Ein Urahn der Waldmaus. In Paläontologie - 100 Jahre Paläontologische Gesellschaft, eds. T. Martin, W. von Koenigswald, G. Radtke, and J. Rust, 176-177. München: F. Pfeil.

Göhlich, U.B. 2012. Tertiäre Urelefantenfunde aus Deutschland. In Elefantenreich - Eine Fossilwelt in Europa, ed. H. Meller, 340 372. Halle/S.: Landesamt für Denkmalpflege und Archäologie Sachsen-Anhalt.

Heinegard, D. 1995. Studies of bone matrix give us insights into bone remodelling. Experientia 51: 195-196. https://doi.org/10.1007/ bf01931088.

Hill, R.C., M.J. Wither, T. Nemkov, A. Barrett, A. D'Alessandro, M. Dzieciatkowska, and K.C. Hansen. 2015. Preserved proteins from extinct Bison latifrons identified by tandem mass spectrometry; hydroxylysine glycosides are a common feature of ancient collagen. Molecular \& Cellular Proteomics 14(7): 1946-1958. https:// doi.org/10.1074/mcp.M114.047787.

Kaplan, F.S., and E.M. Shore. 1998. Encrypted morphogens of skeletogenesis: biological errors and pharmacologic potentials. Biochemical Pharmacology 55: 373-382. https://doi.org/10.1016/ s0006-2952(97)00559-5.

Karl, H.-V., M. Reich, and T. Strietzel. 2013. Die Mastodontenreste im Subherzyn und ein Neufund von Mammut borsoni Kerr, 1792 in einer oberpliozänen Spaltenfüllung Thüringens. Neue Ausgrabungen Und Funde in Thüringen 7(2012-2013): 21-31.

Keely, B.J., P.G. Harris, B.N. Popp, J.M. Hayes, D. Meischner, and J.R. Maxwell. 1994. Porphyrin and chlorin distributions in a Late Pliocene lacustrine sediment. Geochimica et Cosmochimica Acta 58 (17): 3691-3701. https://doi.org/10.1016/0016-7037(94)90159-7.

Klähn, H. 1932. Mastodon arvernensis aus dem Mittelpleistozän von Willershausen und die Bedeutung des Vorkommens für Pliozänfragen. Neues Jahrbuch für Mineralogie etc. (B: Geologie und Paläontologie), Beilagen-Band 68: 149-178.

Knobloch, E. 1998. Der pliozäne Laubwald von Willershausen am Harz (Mitteleuropa). Documenta Naturae 120: 1-302.

Kolibáč, J., B. Adroit, E. Gröning, C. Brauckmann, and T. Wappler. 2016. First record of the family Trogossitidae (Insecta, Coleoptera) in the Late Pliocene deposits of Willershausen (Germany). PalZ. Paläontologische Zeitschrift 90: 681-689. https://doi.org/ 10.1007/s12542-016-0316-6.

Kostyukevich, Y., A. Bugrova, V. Chagovets, A. Brzhozovskiy, M. Indeykina, A. Vanyushkina, A. Zherebker, A. Mitina, A. Kononikhin, I. Popov, P. Khaitovich, and E. Nikolaev. 2018. Proteomic and lipidomic analysis of mammoth bone by high-resolution tandem mass spectrometry coupled with liquid chromatography. European Journal of Mass Spectrometry 24(6): 411-419. https://doi.org/10.1177/1469066718813728.

Krüger, F.J. 1979. Tongrube Willershausen Ein Geologisches Naturdenkmal. Aufschluss 30(11): 389-408.

Laemmli, U. 1970. Cleavages of structural proteins during the assembly of the head bacteriophage T4. Nature 227: 680-685. https:// doi.org/10.1038/227680a0.

Manning, P.L., N.P. Edwards, U. Bergmann, J. Anné, W.I. Sellers, A. van Veelen, D. Sokaras, V.M. Egerton, R. Alonso-Mori, K. Ignatyev, B.E. van Dongen, K. Wakamatsu, S. Ito, F. Knoll, and R.A. Wogelius. 2019. Pheomelanin pigment remnants mapped in fossils of an extinct mammal. Nature Communications 10: 2250. https://doi.org/10.1038/s41467-019-10087-2.

Meischner, D. 1995. Lokalität 2: Willershausen. In 65. Jahrestagung der Paläontologischen Gesellschaft - Exkursionsführer-Exkursion F: Klassische Aufschlüsse im Tertiär Süd-Niedersachsens, ed. Anonymous. Terra Nostra (Schriften der Alfred-WegenerStiftung) 5/95: 217-228

Meischner, D. 2000. Der pliozäne Teich von Willerhausen am Harz. In Europäische Fossillagerstätten, eds. G. Pinna and D. Meischner, 223-228, 261. Berlin and Heidelberg: Springer.

Meischner, D., and J. Paul. 1982. Die pliozäne Fossilfundstelle Naturdenkmal Tongrube Willershausen. In "Wallensen, Wealden, Willershausen, Westersteine" - Arbeitskreis für Paläobotanik und Palynologie, 11.-13.3.1982, Dassel-Exkursion B, D. Meischner, J. Paul, G. Pelzer, and W. Riegel. Courier Forschungsinstitut Senckenberg 56: 147-152.

Morgan, E.F., G.L. Barnes, and T.A. Einhorn. 2008. The bone organ system: form and function. In Osteoporosis, eds. R. Marcus, D. Feldman, D.A. Nelson, and C.J. Rosen, 3-26. San Diego, Calif.: Elsevier/Academic Press.

Reed, M.J., and E.H. Sage. 1996. SPARC and the extracellular matrix: implications for cancer and wound repair. Current Topics in Microbiology and Immunology 213: 81-94. https://doi. org/10.1007/978-3-642-61107-0_6.

Reich, M., and A. Gehler. 2011. Als noch Elefanten durch den Landkreis Northeim streiften. Das Naturdenkmal Tongrube Willershausen. In Deutsche Landkreise im Portrait: Landkreis Northeim, 3rd ed., ed. E. Senger, 16-18. Oldenburg/Oldb.: Kommunikation \& Wirtschaft GmbH.

Reinholt, F.P., K. Hultenby, A. Oldberg, and D. Heinegard. 1990. Osteopontin a possible anchor of osteoclasts to bone. Proceedings of the National Academy of Sciences of the United States of America 87: 4473-4475. https://doi.org/10.1073/pnas.87.12. 4473.

Rietschel, S., and G. Storch. 1974. Außergewöhnlich erhaltene Waldmäuse (Apodemus atavus Heller 1936) aus dem Ober-Pliozän von Willershausen am Harz. Senckenbergiana Lethaea 54(5/6): 491-519.

Schaedler, J.M., L. Krook, J.A. Wootton, B. Hover, B. Brodsky, M.D. Naresh, D.D. Gillette, D.B. Madsen, R.H. Horne, and R.R. Minor. 1992. Studies of collagen in bone and dentin matrix of a Columbian mammoth (late Pleistocene) of central Utah. Matrix 12: 297-307. https://doi.org/10.1016/S0934-8832(11)80082-X.

Schmidt-Schultz, T.H., and M. Schultz. 2004. Bone protects proteins over thousands of years. Extraction, analysis, and interpretation of extracellular matrix proteins in archaeological skeletal remains. American Journal of Physical Anthropology 23: 30-39. https:// doi.org/10.1002/ajpa.10308.

Schmidt-Schultz, T.H., and M. Schultz. 2005. Intact growth factors are conserved in the extracellular matrix of ancient human bone and teeth: a storehouse for the study of human evolution in health and disease. Biological Chemistry 86: 767-776. https://doi.org/ 10.1515/BC.2005.090. 
Schultz, M. 1988. Methoden der Licht- und Elektronenmikroskopie. In Anthropologie: Handbuch der vergleichenden Biologie des Menschen. Band I, 1 Wesen und Methoden der Anthropologie, ed. R. Knussmann, 698-730. Stuttgart/New York: G. Fischer.

Schultz, M. 1997. Microscopic Investigation of Excavated Skeletal Remains: A Contribution to Paleopathology and Forensic Medicine. In Forensic Taphonomy, The Postmortem Fate of Human Remains, eds. W.D. Haglund and M.H. Sorg, 201-222. Boca Raton: CRC Press.

Schultz, M. 2001. Paleohistopathology of bone. A new approach to the study of ancient diseases. Yearbook of Physical Anthropology 44: 106-147. https://doi.org/10.1002/ajpa.10024.

Schultz, M., and R. Drommer. 1983. Möglichkeiten der Präparateherstellung aus dem Gesichtsschädelbereich für die makroskopische und mikroskopische Untersuchung unter Verwendung neuer Kunststofftechniken. In Fortschritte der Kiefer- und GesichtsChirurgie 28. Experimentelle Mund-Kiefer-Gesichtschirurgie. Mikrochirurgische Eingriffe, ed. W. Hoppe, 95-97. Stuttgart/New York: G. Thieme.

Schultz, M., H. Parzinger, D.V. Posdnjakov, T.A. Chkisheva, and T.H. Schmidt-Schultz. 2007. Oldest known case of metastasising prostate carcinoma diagnosed in the skeleton of a 2700-year-old Scythian king from Arzhan (Siberia, Russia). International Journal of Cancer 121: 2591-2595. https://doi.org/10.1002/ijc.23073.

Schweitzer, M.H., W. Zheng, T.P. Cleland, and M. Bern. 2013. Molecular analysis of dinosaur osteocytes support the presence of endogenous molecules. Bone 52: 414-423. https://doi.org/10.1016/j. bone.2012.10.010.

Špinar, Z.V. 1980. Fossile Raniden aus dem oberen Pliozän von Willershausen (Niedersachsen). Stuttgarter Beiträge zur Naturkunde (B: Geologie und Paläontologie) 53: 1-53.

Straus, A. 1969. Beiträge zur Kenntnis der Pliozänflora von Willershausen (VI) - Die Gattung Buxus -. Argumenta Palaeobotanica 3: $57-64$.
Swain, M., and N.W.A. Ross. 1995. Silver stain protocol for protein yielding high resolution and transparent background in sodium dodecyl sulfate-polyacrylamide gels. Electrophoresis 16: 601604. https://doi.org/10.1002/elps.11501601159.

Thomas, B., and S. Taylor. 2019. Proteomes of the past: the pursuit of proteins in paleontology. Expert Review of Proteomics 16(11-12): 881-895. https://doi.org/10.1080/14789450.2019.1700114.

Tuross, N. 1989. Albumin preservation in the Taima-Taima mastodon skeleton. Applied Geochemistry 4: 255-259. https://doi.org/10. 1016/0883-2927(89)90026-7.

Wadsworth, C., and M. Buckley. 2014. Proteome degradation in fossils: investigating the longevity of protein survival in ancient bone. Rapid Communications in Mass Spectrometry 28(6): 605-615. https://doi.org/10.1002/rcm.6821.

Wegele, H. 1914. Stratigraphie und Tektonik der tertiären Ablagerungen von Oldenrode-Düderode-Willershausen. Unpublished $\mathrm{PhD}$ Thesis, Georg-August University Göttingen, 1-38. Göttingen.

Westphal, F. 1967. Erster Nachweis des Riesensalamanders (Andrias, Urodela, Amphibia) im europäischen Jungpliozän. Neues Jahrbuch für Geologie und Paläontologie, Monatshefte 1967(2): 67-73.

Wiemann, J., M. Fabbri, T.-R. Yang, K. Stein, P.M. Sander, M.A. Norell, and D.E.G. Briggs. 2018. Fossilization transforms vertebrate hard tissue proteins into $\mathrm{N}$-heterocyclic polymers. Nature Communications 9: 4741. https://doi.org/10.1038/ s41467-018-07013-3.

Wolkenstein, K., and G. Arp. 2021. Taxon- and senescence-specific fluorescence of colored leaves from the Pliocene WillershausenLagerstätte, Germany. PalZ. Paläontologische Zeitschrift. https:// doi.org/10.1007/s12542-020-00538-3.

Wysokowski, M., M. Zaton, V.V. Bazhenov, T. Behm, A. Ehrlich, A.L. Stelling, M. Hog, and H. Ehrlich. 2014. Identification of chitin in 200-million-year-old gastropod egg capsules. Paleobiology 40(4): 529-540. https://doi.org/10.1666/13083. 